\title{
Effectiveness of monetary policy in controlling inflation in Pakistan
}

\author{
Muhammad Azhar Khan ${ }^{1}$, Sonia Haroon² \\ ${ }^{1}$ Department of Economics, University of Haripur, Khyber Pakhtoonkhawa, Haripur, Pakistan \\ 2 Department of Economics, Government postgraduate college \# 1, Abbottabad, Pakistan \\ * Corresponding author:
}

\section{Abstract}

The objective of the study is to examine the role of monetary policy to control inflation and boost economic growth in Pakistan during the period of 1970 to 2010. The results show that there is a long-run equilibrium among inflation, money supply and GDP. In addition, the results indicate that monetary policy is a powerful tool in order to control inflation in Pakistan. The important policy implication is that inflation in Pakistan can be cured by sufficiently tight monetary policy coupled with low scale borrowing by government from financial institution. At the same time economic growth requires to be sustained.
\end{abstract}

\section{ARTICLE INFORMATION}

\section{Received: 25 November 2013 \\ Revised: 12 January 2014}

Accepted: 25 January 2014

DOI 10.31581/jei.v1i1.106

\section{Introduction}

There has been consensus among macroeconomists that inflation sometimes impedes economic growth, even moderate inflation damage real growth Cecchetti (2000). Inflation is the most debatable issue in Pakistan and economy of Pakistan had double digit inflation since long. Monetary policy is an important instrument of stabilization policy. It has been found as an effective instrument in controlling inflation. It helps to control the persistent rise in price level by controlling money supply. But if we look into the present scenario of price hike and continuous tight monetary policy announced by State bank of Pakistan (SBP), we come to a fair conclusion that policy followed by SBP failed to curb inflation in Pakistan in recent years. The most of the economists agree that high growth of money supply is the major cause of high rate of inflation in Pakistan.

Inflation and money supply are most important issues of economic development for all countries in the world. State bank of Pakistan (SBP) pays high attention to control inflation by controlling money supply. According to SBP Pakistan crossed its single digit inflation in 1970 's for the first time and came back in single digit again in 1990,s. For the first seven years inflation remained at an average of $11.4 \%$ due to some material and natural causes like fuel, electricity, transport and communication, lower investment, increase in prices of food items. During this period monetary policy was framed up to achieve 2 objectives i.e. to stabilize macro-economic indicators, sustained economic growth, and interest rate in free market. Table 1shows the inflation rate in Pakistan for 20 consecutive years.

From 2003 to 2010 average inflation in Pakistan was $10.15 \%$ whereas highest $25.33 \%$ in august 2008 and lowest $1.41 \%$ in July 2003. Conceptually an increase in money supply in the long run results in a higher rate of inflation and thus provides base for the quantity theory of money. Some studies showed that Inflation is a monetary phenomenon in Pakistan while Bilquees (1988), is of the view, that food factors are the causes of inflationary process in Pakistan.

\begin{tabular}{cl}
\multicolumn{2}{l}{ Table 1: Inflation Trends in Pakistan } \\
\hline YEAR & INFLATION RATE \\
\hline 1991 & $12 \%$ \\
1992 & 10.6 Decline of almost $2 \%$ \\
1993 & $9.8 \%$ (decline) \\
1994 & $11.3 \%$ (raise) \\
1995 & $13 \%$ (raise) \\
1996 & $10.8 \%$ decline of $2 \%$ \\
1997 & $11.8 \%$ (raise) \\
1998 & $7.8 \%$ (decline) \\
1999 & 5.5 (decline) \\
2000 & $3.4 \%$ (decline) \\
2001 & $4.4 \%$ (raise) \\
2002 & 3.5 (decline) \\
2003 & 3.1 (lowest ever recorded) \\
2004 & $4.4 \%$ (raise) \\
2005 & $9.3 \%$ (raise) \\
2006 & $7.9 \%$ (decline) \\
2007 & $6.5 \%$ (decline \\
2008 & $11.99 \%$ (raise) \\
2009 & $20.7 \%$ (highest ever recorded) \\
2010 & $12.69 \%$ (decline) \\
\hline Source: State Bank of Pakistan (various issues).
\end{tabular}

"According to SBP Inflation averaged $14.2 \%$ in the first four months of the current fiscal year (July October 2010), compared to the same period. Inflation in Oct stood at 15.3\%.The principal contributor to the recent surge in inflation has been the sharp increase in food inflation. Food inflation averaged 13.7\% from November 2009 to July 10, but rose sharply to an average of $19 \%$ during (August October) 2010. Food inflation was up $20.1 \%$ in October. A cursory looks at the inflation figures would show that food inflation alone contributed $55 \%$ in the rise of overall inflation. "( Ashfaque 2010).

Given this background, the current study is intended to identify the variables that affect inflation. SBP changed monetary policy from an easy monetary policy to a strict policy in order to control inflation in Pakistan. But still in current scenario increase in interest rate is neither slowing inflation nor curbing government expenditure 
but just slowing down the private sector and discourages private investment which is already facing an extremely difficult situation. SBP must $b$ independent of government influence in choosing the instruments to achieve a desirable rate of inflation.

The main objectives of the study are to investigate whether monetary policy in Pakistan is an effective tool to control inflation and to explore which factors are responsible for price surge in Pakistan. This study also suggests recommendations which help in controlling inflation in Pakistan.

\section{Literature review}

The aim of economic policies is to promote public welfare and monetary policy helps to fulfill this objective by controlling inflation Akhtar (2008). Inflation is the most important aspect of Pakistan economy and calls for urgent. Different authors gave different views regarding this important issue. Most of them have agreed that money supply causes inflation in Pakistan. An increase in money supply over the long-run results in a higher rate of inflation and thus provides support for the quantity theory of money Kemal (2006). According to Gerald et al (2009) in 166 countries across the world, the relationship between inflation, growth and excessive money supply is still contentious however; there is a positive correlation between them. According to Qayyum (2006) in Pakistan, inflation is actually a monetary issue. On the one side increase in money supply caused a noticeable rise in inflation and on the other hand, inflation made same impact on growth of GDP. So increase in money supply ultimately increased rate of inflation and growth of GDP in Pakistan hence; there was positive relationship between money supply and inflation. The excessive money supply growth had been a significant contributor to the rise in inflation in Pakistan.

Ali et al (2008) investigated that there was a big difference between effectiveness of fiscal and monetary policy in terms of short run and long run basis. Monetary policy was a powerful tool than fiscal policy in order to develop economic growth in case of south Asian economies. There was long run relationship among GDP growth rate, Broad Money and Fiscal balance. Money supply appeared as a significant variable in both short run and in long run, while Fiscal balance was insignificant in short run as well as in long run. According to Waliullah et al (2011) in developing countries like Pakistan, monetary policy makes a huge impact on money supply, price changes and GDP as there is a long term relationship between three of them.

Rehman (2005) investigated that monetary policy has positively great effect on economic growth in Bangladesh. The impact of fiscal policy was almost un-noticeable. According to data used by study revealed that monetary policy is practically more implemental than fiscal policy as it enhances monetary activities and volume of transactions to achieve desired goals.

According to Ul Haque et al. (2006) authorities of monetary policy in Pakistan used broad money supply as a medium to adjust rate of inflation in Pakistan. Inflation and money supply should have positive effect on the growth of GDP but it looks like having negatively affected by inflation. Hussain (1989) analyzed the relationship between real permanent income $\left(\mathrm{RGNP}^{p}\right)$ and money supply and showed that disequilibrium of money market was adjusted through the changes in price and controlling supply of money.

Upadhyaya (1991) showed the effect of money supply in Pakistan over the last year was quite immense but it became insignificant for all lagged periods anyhow total impact was visible. Agha et al (2005) described that inflation and money supply had positive correlation as far as monetary policy tools were concerned.

Qayyum (2008) showed that the monetary authority is successful in controlling inflation, when it is capable of controlling the money supply. It was also concluded that in the recent years SBP failed to control money supply and hence rate of inflation within the set target level.

While some other studies showed monetary policy was the cause of high inflation in Pakistan. Malik (2006) showed that from last thirty years in Pakistan monetary policy tools were the reason of high rate of inflation. On the other hand Abbas (2009) showed that inflation was not the base of economic growth but the relative internal and external factor. He further concluded that on the basis of the study of monetary policy of state bank of Pakistan 2007-2008 and 2008-2009 monetary policy tools could not give desired results without improving supply side management.

Schimmelpfennig (2006) showed that from the last one year monetary policy was the main factor causing inflation. Monetary policy tools were the main reason for the uplifting of inflation rate in Pakistan where gross domestic product (GDP), wheat support and NEER (nominal effective exchange rate) appreciation were insignificant factors. Khan et al (2007) were of the view that the most important determinants of inflation in 2005-06 were adaptive expectations, private sector credit and rising import prices, whereas the role of fiscal policy to inflation was negligible.

A brief glance on the existing literature on the effectiveness of monetary policy in Pakistan manifests that researchers consider monetary policy as useful and powerful tool in regulating money supply in Pakistan. If properly managed, this policy can be implemented to achieve desirous results if managed with true spirit. The present paper aims at to investigate the effectiveness of monetary policy in curbing rampant inflation and to sustain economic growth in the country.

\section{Methodology and interpretation of results}

Inflation can be explained and classified on the basis of different factors that cause inflation. It is a very hot and burning topic in all over the world and present era. Every country wants to control it. There are different theories of inflation. The first theory put forward was QTM. The theory states that increase in money growth leads to equal changes in inflation. It assumes that velocity and output in the long run remain the same. Several studies have been carried out to check whether inflation in Pakistan depends on QTM or not. Khan and Qasim (1996) and Nasim (1995) shows that inflation is a monetary phenomena.

Conceptually, the general price level $\mathrm{P}$ is function of money supply and real demand for money. Mathematically same can b expressed as

$$
P=\frac{M}{\mathrm{f}(\mathrm{Y}, \mathrm{r}+\pi)}
$$

Where $\mathrm{P}=$ Price level

$\mathrm{Y}=$ real output

$\mathrm{r}=$ Real interest rate and

$\pi=$ Expeted rate of inflation

$\mathrm{r}+\pi=$ real demand for money and it remains constant in short run

If Real demand for money $f(Y, r+\pi)$ is fixed then price is directly proportional to supply of money (M), usually rate of inflation represents the price level. Theory states that the rate of inflation is closely related to the growth of nominal money supply (M). This can $\mathrm{b}$ expressed mathematically.

$$
\frac{\Delta P}{P}=\frac{\Delta M}{M}-\frac{\Delta f(Y, r+\pi)}{\Delta f(Y, r+\pi)}
$$

Where $\frac{\Delta p}{p}=$ growth rate of price level which is same as inflation $(\pi)$.

The expression (2) states that the rate of inflation is equal to growth rate of nominal money supply $(\mathrm{M})$, growth rate of real money demand. It is obvious from expression (1) that rate of inflation is closely related to money supply, However real output has also significant effect on rate of inflation.

Monetary policy if properly managed is very effective in controlling the level of money supply. Generally, three tools are operated to regulate money supply in the country, these discount rates, Open Market Operation (OMO) and reserve requirements. Money supply depends upon 
1. Public preferences between currency and demand deposits.

2. Holding of excess reserves by banks and borrowing of reserves at discount rate.

The latter activity is function of interest rate. It brings changes in LM curve. Both monetary and fiscal policies are operated simultaneously to get desirous results. The present study focuses more on effectiveness of monetary policy in controlling the money supply thus, curbing the inflation.

One of the main objectives of the current study is to empirically investigate the relationship between inflation, money supply and GDP in Pakistan both in long run and short run. The current study used cointegration technique to verify the long run relationship. Order of integration of the variables is checked by using stationarity test i.e. ADF and Engle-Granger approach of cointegration.

Study used Inflation as dependent variable while Money Supply and GDP are as independent Variables. This study used annual data of 40 years from 1970-2010 for Inflation, GDP and money supply. The annually data on real GDP is taken from WDI 2010, Consumer Price WDI - 2010 and money supply are taken form State Bank of Pakistan Monetary Statistics.

\section{Econometric model}

In order to generate the OLS estimates the following regression is run.

$$
I N F=\beta_{0}+\beta_{1}(G D P)+\beta_{2}\left(\ln M_{1}\right)+\mu
$$

The results have been presented in Table 2 .

Table 2 shows the results of regression by simple OLS using Eviews7 and MS Office Excel 2007. Study run simple OLS on data and run regression but results are insignificant. Value of $R(0.028491)$ is very low which shows variables are not correlated. Ln $\left(\mathrm{M}_{1}\right)$ and GDP are not statistically significant because its value is very low and $\mathrm{F}$ statistics are also very low so study shows regression is insignificant.
Cointegration is an econometric property of time series variables. If two or more series are themselves non-stationary, but a linear combination of them is stationary, then the series are said to be cointegrated. It is often said that cointegration is a means for correctly testing hypotheses concerning the relationship between two variables having unit roots.

\begin{tabular}{ll} 
Table 2: Regression Results & \\
\hline Constant & $\mathbf{1 2 . 8 5}$ \\
\hline standard error & 3.613 \\
T- value & $3.55^{\star}$ \\
P- value & 0.001022 \\
In $\left(\left(\mathrm{M}_{1}\right)\right)$ & -0.46503 \\
standard error & 0.4977 \\
T- value & -0.9343 \\
P- value & 0.35604 \\
GDP & -0.2296 \\
standard error & 0.362 \\
T- value & -0.6335 \\
P- value & 0.53017 \\
R Square & $\mathbf{0 . 5 2 8}$ \\
\hline *indicates the variable is significant at 1\% level of significance.
\end{tabular}

Dependent Variable: Inflation

The two main methods for testing for cointegration are:

1. TheEngle-Granger two-step method.

2. The Johansenprocedure.

In the study, Engle-Granger is used to test the cointegration between variables. The first step is to carry out ADF test to check the stationarity of variables. The condition for the cointegration is that all variables satisfy the same order of integration. The results of ADF are presented in the following Table 3.

Table 3: Unit root test

\begin{tabular}{|c|c|c|c|c|c|c|c|}
\hline Variables & & ADF & $1 \%$ & $5 \%$ & $10 \%$ & Order of Integration & $\mathbf{P}$ \\
\hline Inflation & $\begin{array}{l}\text { Level } \\
1^{\text {st }} \text { difference }\end{array}$ & $\begin{array}{l}-3.158 \\
-5.982\end{array}$ & $\begin{array}{l}-3.6 \\
-3.61^{*}\end{array}$ & $\begin{array}{l}-2.9 \\
-2.93^{* *}\end{array}$ & $\begin{array}{l}-2.6 \\
-2.60\end{array}$ & $\begin{array}{l}\mathrm{I}(0) \\
\mathrm{I}(1)\end{array}$ & $\begin{array}{l}0.03 \\
0.00\end{array}$ \\
\hline $\begin{array}{l}\text { Money Supply In } \\
\left(\mathrm{M}_{1}\right)\end{array}$ & $\begin{array}{l}\text { Level } \\
1^{\text {st }} \text { difference }\end{array}$ & $\begin{array}{l}-0.674 \\
-5.870\end{array}$ & $\begin{array}{l}-3.560 \\
-3.610^{\star}\end{array}$ & $\begin{array}{l}-2.936 \\
-2.93^{* *}\end{array}$ & $\begin{array}{l}-2.606 \\
-2.60\end{array}$ & $\mathrm{I}(1)$ & $\begin{array}{l}0.99 \\
0.00\end{array}$ \\
\hline GDP & $\begin{array}{l}\text { Level } \\
1^{\text {st }} \text { difference }\end{array}$ & $\begin{array}{l}-6.256 \\
-10.71\end{array}$ & $\begin{array}{l}-3.605 \\
-3.610^{*}\end{array}$ & $\begin{array}{l}-2.936 \\
-2.93^{* *}\end{array}$ & $\begin{array}{l}-2.606 \\
-2.607\end{array}$ & $\begin{array}{l}\mathrm{I}(0) \\
\mathrm{I}(1)\end{array}$ & $\begin{array}{l}0.00 \\
0.00\end{array}$ \\
\hline
\end{tabular}

* indicate statistically significant at $1 \%$

** indicate statistically significant at $5 \%$

Table 3 shows all variables are stationary at first difference leading to reject null hypothesis that variables have unit root. Inflation is stationary at $\mathrm{I}(0)$ at $5 \%$ level of significance Inflation is also stationary at $\mathrm{I}(1)$ at $1 \%$ at $1^{\text {st }}$ difference we are $99 \%$ confidant to reject null hypothesis that inflation has unit root. GDP is stationary at $\mathrm{I}(0)$ at $1 \%$ level of significance. GDP is also stationary at $\mathrm{I}(1)$ at $1 \%$ at $1^{\text {st }}$ difference we are $99 \%$ confidant to reject null hypothesis that GDP has unit root. $\mathrm{Ln}\left(\mathrm{M}_{1}\right)$ is not stationary at $\mathrm{I}(0)$. But stationary at $\mathrm{I}(1)$ at $1 \%$ at 1 st difference we are $99 \%$ confidant to reject null hypothesis that $\ln \left(\mathrm{M}_{1}\right)$ as unit root.

All the variables are first tested for stationarity with intercept using the Augmented Dickey- Fuller (ADF). The test results (ADF) table 1.3 indicate that the Gross Domestic Product(GDP) and Inflation are stationary at level and also at 1st difference and is integrated of order zero $\mathrm{I}(0)$ and order one $\mathrm{I}(1)$, while Money supply $\ln \left(\mathrm{M}_{1}\right)$ is not stationary at level but at first difference. It is integrated of order one I(1). There ADF statistics are more negative than the level of significance at which it is being tested. So all variables satisfy the order of integration I(1).

The second step towards cointegration test is to generate residuals by running the simple regression (4) and generate residuals through expression (5).

$$
\begin{aligned}
& I N F=\beta_{0}+\beta_{1}(G D P)+\beta_{2}\left(\ln M_{1}\right)+\mu \\
& e=I N F-\beta_{0}-\beta_{1}(G D P)-\beta_{2}\left(\ln M_{1}\right)+\mu
\end{aligned}
$$

ADF is performed on residuals and if they happened to have order of integration $\mathrm{I}(0)$, that is, fulfilling the stationarity at level, then it can be concluded that long run relationship between variables exists. The results of ADF on residuals are presented in Table 4 and Table 5 respectively.

Table 4: Engle-Granger First Stage Regression For generation of residuals

\begin{tabular}{llcll}
\hline Variable & coefficient & Std. Error & t-statistics & Prob \\
\hline GDP & -0.229626 & 0.362448 & -0.633542 & 0.5302 \\
Ln $\left(\mathrm{M}_{1}\right)$ & -0.465026 & 0.497725 & -0.934303 & 0.3560 \\
C & 12.85819 & 3.613786 & 3.558095 & 0.001 \\
R-squared & 0.028491 & \\
Adjusted R-squared & -0.022641 & \\
S.E of regression & 5.537568 & \\
Sum squared residuals & 11165.257 & \\
F-Statistics & 0.557207 & \\
Probability (F-statistics) & 0.557416 & \\
Durban Watson stat & 0.878328 & \\
\hline
\end{tabular}

Dependent Variable : Inflation, Included observation: 41, Sample :1970 2010

Table 5 shows residuals are stationary at $\mathrm{I}(0)$. The Engle-Granger $5 \%$, $10 \%$ critical values of stochastic term $\left(\mu_{\mathrm{t}}\right)$ are less negative than ADF statistics, the conclusion is that the estimated $\mu$ is stationary (it does not have unit root) and, therefore, inflation, money supply (ln $\left.\mathrm{M}_{1}\right)$ and GDP are cointegrated. The results give evidence that there exist long run relationship between Inflation, money supply ( $\left(n \mathrm{M}_{1}\right)$ and GDP. 
After obtaining long run relationship between inflation, money supply and GDP. The next step is to work out the short run dynamics of the model.

Table 5: Engle-Granger First Stage ( $U=$ Resd) Stationarity of Residuals

\begin{tabular}{ll}
\hline Variables (inflation) & level \\
\hline ADF test statistics & -3.265972 \\
Test critical values & \\
$1 \%$ & -3.605 \\
$5 \%$ & -2.9369 \\
$10 \%$ & -2.60685 \\
Order of cointegration & $\mathrm{I}(0)$ \\
Probability & 0.0234 \\
\hline
\end{tabular}

For this purpose one-time lagged value of residual is incorporated into different models as:

$$
\Delta I N F=\beta_{0}+\beta_{1} \Delta \ln \left(M_{1}\right)+\beta_{2} \Delta G D P+\gamma \operatorname{resd}(-1)+\mu
$$

Where $\gamma$ is error correction term identifying the short run dynamics of the model.

\begin{tabular}{lllll}
\multicolumn{4}{l}{ Table 6: Error Correction Term } \\
\hline Variable & coefficient & Std. Error & t-statistics & prob \\
\hline $\mathrm{D}(\mathrm{GDP})$ & 0.070619 & 0.230472 & 0.306411 & 0.761 \\
$\mathrm{D}\left(\mathrm{In} \mathrm{M}_{1}\right)$ & 1.427178 & 7.563368 & 0.188696 & 0.8514 \\
RESD01(-1) & -0.431254 & 0.139900 & -3.082583 & 0.0039 \\
$\mathrm{C}$ & -0.0730343 & 1.335793 & -0.052660 & 0.9583 \\
R-squared & 0.225400 & \\
Adjusted R-squared & 0.160849 & \\
S.E of regression & 4.598479 & \\
Sum squared residuals & 761.2624 & \\
F-Statistics & -115.6795 & \\
Probability (F-statistics) & 3.491857 & \\
Durban Watson stat & 1.7044 & \\
\hline
\end{tabular}

\section{Dependent Variable: D (Inflation)}

Included observation: 41

Sample: 19702010

The Error correction mechanism (ECM) is used to find short run dynamics in Table 6 ECM finds that $57 \%$ disequilibrium comes to end in one year. From the cointegrating analysis, the study concludes that inflation has a positive long-run association with money supply (ln $\left(\mathrm{M}_{1}\right)$ and a negative relationship with GDP growth and negative association between inflation and output implies that any increase in output in the short run resulting from demand stimulus results in a decline in the output.

The results clearly reveal that there is long run as well as short run relationship among the variables under consideration. Money supply and GDP appeared as a significant variable in both short run as well as in long run. The results show that monetary policy is a powerful tool in order to control inflation in Pakistan.

\section{Conclusion}

This paper examines the effectiveness of monetary policy to control inflation and boost growth in Pakistan during the period 1970 to 2010, using Engle-Granger cointegration technique, in order to test whether the GDP and Money supply $\left(\ln \left(\mathrm{M}_{1}\right)\right.$ ) have a significant relationship with Inflation. The results show that there is a long-run equilibrium among inflation, money supply and GDP. For estimating short run equilibrium the Error Correction Model is applied. The relationship among variables also predicts short run equilibrium. The results show that monetary policy is a powerful tool in order to control inflation in Pakistan.

The important conclusion that emerged from the study is that the money supply growth has been an important contributor to the rise in inflation in Pakistan during the study period. This is to be concluded that inflation in Pakistan is a monetary phenomenon. This may be due loose monetary policy adopted by the State Bank of Pakistan to possess the high priority of the growth objective. It is argued that the policies to possess output growth through money supply only have short run effect on real output but generate inflation. Indeed, the recent act of tightening the monetary policy by the State Bank of Pakistan supports the monetarist argument that the inflation in Pakistan is a monetary phenomenon. The important policy implication is that inflation in Pakistan can be cured by sufficiently tight monetary policy coupled with low scale borrowing by government from financial institution. At the same time economic growth requires to be sustained. The formulation of monetary policy must consider development in the real and financial sector and treat them as constraints on the policy.

In face of results generated in the present study, it can be concluded that although monetary policy is powerful tool in curbing inflation and boosting economic growth. But when we look at the present scenario of Pakistan, situation gives different picture. Inflation rampant, economic growth is slow. This is apparently due to mass borrowing of government from banks. It then swallows the effectiveness of monetary policy, so in review of the result of present study following recommendations are put forward.

i. Government is required to abstain from getting mass borrowing from banks.

ii. Measures need to be taken by monetary policy managers to make the value of rupee stable.

iii. Foreign aid is required to be properly utilized.

iv. Economic growth needs to be balanced.

\section{References}

Abbas, S.K. (2009). Keynes is Back: Global Economic Depression Monetary Policy Operations FY-02 \& FY-09 Pakistan's Economic Scenario. Market Forces - Journal of Management Thought, 5 (2), 59-62.

Ali, S., Irum,S., Ali,A. (2008). Whether Fiscal Stance or Monetary Policy Is Effective For Economic Growth In case of South Asian Countries? The Pakistan Development Review, 47 (4), 791-799.

Agha, A.I., Ahmed, N., Mubarik, Y.A., Shah,H. (2005). Transmission Mechanism of Monetary Policy in Pakistan. SBP Research Bulletin, 1(1), $1-24$.

Akhtar, D.S. (2008). The effectiveness of monetary policy in Pakistan. Speech at the convocation of the Institute of Business Management, Karachi, 6.

Ashfaque, D.H.k. (2010). Why the discount rate hike? Newspaper The News 6 December 2010.

Bilquees, F. (1988). Inflation in Pakistan: Empirical Evidence on the Monetarist and Structuralist Hypothesis. The Pakistan Development Review, 27(2), 109-130.

Cecchetti, S.G. (2000). Making Monetary Policy: Objectives and Rules. Oxford Review of Economic Policy, 16(4), 43-59.

Gerald, P.D., and Fisher, M. (2009). Inflation and Monetary Regimes. working paper, 2009-26.

Hussain, M.A. (1989). A Monetary Model of inflation for Bangladesh 19741985. The Pakistan Development Review, 28(2), 133-155.

Kemal, M.A. (2006). Is Inflation in Pakistan a Monetary phenomenon? Pakistan Development Review, 45(2), 213-220.

Khan, A.A., Bukhari, S.K.H., and Ahmad, Q.M. (2007). Determinants of Recent Inflation in Pakistan. Development Center (SPDC), Research Report No 66.

Malik, W.S. (2006). Money, Output, and Inflation: Evidence from Pakistan. The Pakistan Development Review, 45(4), 1277-1286.

Nasim, A. (1995). Determinants of Inflation in Pakistan. Karachi: State Bank of Pakistan, 35(4).

Qasim, M.A., and Khan, A.H. (1996). Inflation in Pakistan Revisited. The Pakistan Development Review, 747-59.

Rahman, M.H. (2005). Relative Effectiveness of Monetary and Fiscal Policies on Output Growth in Bangladesh. Bangladesh Journal of Political Economy, 22, 1-2.

Qayyum, A. (2006). Money, Inflation and Growth in Pakistan. The Pakistan development review, 45(2), 203-212.

Qayyum, A. (2008). Does Monetary Policy Play Effective Role in Controlling Inflation in Pakistan. Pakistan Institute of Development Economics Islamabad Pakistan 2008, 13080, posted 30. January 2009.

Schimmelpfennig, A., and Khan, M.S. (2006). Inflation in Pakistan: Money or Wheat? IMF Working Paper No./06/60 Middle East and Central Asia Department.

Ul Haque, N., Qayyum, A. (2006). Inflation Everywhere is a Monetary Phenomenon. Pakistan Development review, 45(2), 179-18.

Upadhyaya, K.P. (1991). The efficiency of monetary and fiscal policies in developing countries, an application of the St. Louis equation. Indian 
Economic Journal, 37(2), 101-108. International Journal of Business and Social Science, 2(1), 2011198.
Waliullah., and Rabbi, F.D. (2011). Effectiveness of Monetary Policy in

Pakistan: Empirical Evidences based on Bound Test Approach. International Journal of Business and Social Science, 2(1), 190. 